\title{
PRESERVING THE RIGHT TO CONERONTATION- A NEW APPROACH TO HEARSAY EVIDENCE IN CRIMINAL TRIALS
}

\author{
In all criminal prosecutions, the accused shall enjoy the right \\ . . to be confronted with the witnesses against him. ${ }^{1}$
}

\section{INTRODUCTION}

Every state except Idaho has either statutory or constitutional language reflecting the sixth amendment's right to confrontation. ${ }^{2}$ A result similar to that required by the Constitution is provided by the commonlaw hearsay evidence rule, which prohibits the admission of evidence which the declarant has not given directly at trial and upon which he cannot be cross-examined. ${ }^{8}$ However, the hearsay rule has been qualified by a number of specific exceptions developed by the courts and legislatures over the last two hundred years. ${ }^{4}$ Perhaps because of the similarities in result between the two rules, the courts have generally held that the right to confrontation is not violated by the admission of out-of-court statements which fit within one of the established exceptions to the hearsay rule. ${ }^{5}$ However, recent developments in the law of hearsay suggest a need to reconsider whether the delimitation of the constitutional right can be relegated solely to the minimally acceptable degrees of trustworthiness controlling the admission of hearsay.

1 U. S. Const. amend. VI.

2 See 5 Wigmore, Evidence \$1397, at 127 n.1 (Supp. 1962) for the various state provisions. Added to this list should be ArAskA CoNst. art. I \&11 (accused has right "to be confronted with the witnesses against him"). Idaho's protection must rest on the due process clause of her constitution. Several states use the language "to meet witnesses face to face." See, e.g., State ex rel. Gladden v. Lonergan, 201 Ore. 163, 269 P.2d 491 (1954) (this phrase forces the state to produce witnesses for the accused). Compare State v. Dehler, 257 Minn. 549, 102 N.W.2d 696 (1960).

The protection afforded by a statutory confrontation clause is obviously dependent on the whims of the legislatures. Compare People v. Ashley, $42 \mathrm{Cal}$. 2d 246, 267 P.2d 271, cert. denied, 348 U.S. 900 (1954) (hearsay admissible under CAI. PENAI CODE $\$ 646$ does not violate statutory confrontation guarantee), with People v. Nisonoff, 293 N.Y. 597, 59 N.E.2d 420 (1944) (autopsy report-admissible under prior statutory guarantee-held no violation of recently adopted constitutional guarantee).

3 See Dysart Peerage Case, 6 App. Cas. 489, 503-04 (1881). See generally 9 Holdsworte, A History OF ENGLISH LAW 214-19 (3d ed. 1944) ; MCCORMICK, EvIDENCE \$§ 223-25 (1954) [hereinafter cited as MCCoRMrck].

4 See generally 5 Wigmore, Evidence $\$ \$ 1420-26$ (3d ed. 1940) [hereinafter cited as WIGMORE].

ธ See, e.g., Mattox v. United States, 156 U.S. 237 (1895). 
The most significant development in the law of hearsay is the Uniform Rules of Evidence. ${ }^{6}$ In order to effectuate the general policy of admission of all probative evidence, the Commissioners on the Uniform Rules have significantly expanded many of the exceptions to the general rule. ${ }^{7}$ The Rules enlarge the concept of admissible hearsay to include, for example, evaluative official reports, declarations against penal interest, a co-conspirator's statement if only relevant to the conspiracy, and admission of a prior felony judgment to show any fact necessary for that judgment. Moreover, the Uniform Rules eliminate for some exceptions the common-law requirement of unavailability of the declarant.

Unfortunately, although the Commissioners were aware of particular constitutional objections, ${ }^{8}$ they did not formulate their proposed exceptions to meet them. However, the studies made by several states considering the adoption of the Uniform Rules ${ }^{9}$ show a consciousness of the constitutionally permissible limits of hearsay exceptions. ${ }^{10}$ This Note will attempt to establish standards for a viable interpretation of the confrontation clause, examine the historical interrelationship between the right to confrontation and the hearsay rule, and will propose an analytical approach to be applied to offered hearsay to preserve this constitutional protection.

\section{The Confrontation Clause}

The constitutional guarantee of confrontation is by no means free from ambiguity, for the words could be read as simply insuring to the accused the right to be present when a witness is giving damaging testimony. This reading would be consistent with the suggestion that a prime reason for the inclusion of the clause was probably the fear of ex parte

6 Suggestions for reformation of evidentiary rules long antedated the Uniform Rules of Evidence. See, e.g., 5 WIGMORE $\$ \$ 1368-1400$; Chadbourn, Bentham and the Hearsay Rule-A Benthamic View of Rule 63(4)(c) of the Uniform Rules of Evidence, 75 HaRv. L. REv. 932 (1962); Morgan, The Hearsay Rule, 12 WASH. L. REv. 1 (1937).

7 See Uniforar Rule of Evidence 7. Compare Moder Code of Evidence rule 503 (a) (1942) (the Code was not adopted by any jurisdiction).

8 UNIFORM RUle of Evidence, prefatory note, at 163; UNIFORM RULE of EviDENCE 7, comment.

9 Kansas, the Virgin Islands, and the Panama Canal Zone have incorporated the Uniform Rules in their system of laws. The New Jersey Supreme Court has adopted a modified version of the Rules, effective June 1, 1965, unless revised by the legislature. In addition to the above jurisdictions, California, Washington, Utah, and Oklahoma have conducted studies on adopting the Rules. Letter from Francis D. Jones, Executive Secretary, National Conference of Commissioners on Uniform State Laws, to the University of Pennsylvania Law Review, Sept. 23, 1964, on file in Biddle Law Library, University of Pennsylvania Law School.

10 See 4 Cal. Law Revision Comm. Reports, Reconmendations, and Studies 450 (1963) [hereinafter cited as CaI. Study]. N.J. Supreme Court Comm. on EVIDENCE, REPORT 142-52, 192 (1963) [hereinafter cited as 1963 N.J. REPORT]; Utar Supreare Court Comm. on Uniform Rules of Evidence rule 63(3), comment (Final Draft 1959) [hereinafter cited as UTAF STUDY].

Compare Chadbourn, supra note 6; McKay, The Right to Confrontation, 1959 WASH. U.L.Q. 122; Quick, Hearsay, Excitement, Necessity, and the Uniform Rules: A Reappraisal of Rule 63(4), 6 WAYNE L. REv. 204 (1960). 
or star chamber proceedings. ${ }^{11}$ In fact some jurisdictions hold that the guarantee is satisfied as long as the prosecution presents a witnesswhether the declarant or not.12 However, "confront" connotes more of an active participation by the defendant with the witnesses and thus can reasonably be read as including an opportunity to cross-examine. ${ }^{13}$ "Witnesses" similarly must mean the declarants, rather than any witnesses who recount what the declarants or original documents said. If the sixth amendment were construed not to require the production of the declarant of the damaging statement, the accused's right of cross-examination would then be emasculated.

A certain notion of fairness has already pervaded the courts' general treatment of evidence in criminal trials. ${ }^{14}$ It arguably follows that the due process clause could effectively prevent the patent abuses in admitting hearsay statements. However, to suggest that the accused is sufficiently protected by the due process clause would be to regard the confrontation clause merely as a constitutional anachronism. ${ }^{15}$ Although the available documentary history of the Bill of Rights provides no determinative guidelines for the ongoing reinterpretation of the clause, ${ }^{16}$ it must be assumed

11 See Snyder v. Massachusetts, 291 U.S. 97, 107 (1934); Dowdell v. United States, 221 U.S. 325, 330 (1911); Mattox v. United States, 156 U.S. 237, 242 (1895); State v. Waldron, 16 R.I. 191, 14 Atl. 847 (1888). Compare People v. Dolgin, 415 I1l. 434, 450, 114 N.E.2d 389, 397 (1953), in which the court held that the accused has no vested rights in rules of evidence, and no constitutional objection will be heard in a criminal trial unless accused has had no "fair opportunity to make a defense and to submit facts to the jury."

Ex parte proceedings no longer represent a serious threat to the individual, for constitutional protection against them has been recognized. $C f$. In re Oliver, 333 U.S. 257 (1948).

12 See, e.g., State v. Murphy, 16 R.I. 528, 533 (1889).

13 See Webster, New International Dictionary 477 (3d ed. 1964) ("to stand facing or opposing, esp. in challenge, defiance, or accusation").

14 See, e.g., United States v. De Sisto, 329 F.2d 929 (2d Cir.), cert. dertied, 377 U.S. 979 (1964); People v. Crump, 5 I11. 2d 251, 268, 125 N.E.2d 615, 624 (1955); People v. Timmons, 300 Mich. 653, 660, 2 N.W.2d 804, 807 (1942) (concurring opinion); cf. Bridges v. Wixon, 326 U.S. 135, 153-54.(1945).

15 The accused can be protected from ex parte hearings by the speedy-and-public trial provision of the sixth amendment. $C f$. In re Oliver, 333 U.S. 257, 267-68 (1948).

Courts have at times indicated that against which the confrontation clause does not protect. See, e.g., Costello v. United States, 350 U.S. 359 (1955) (hearsay before a grand jury); Wilson v. United States, 221 U.S. 361, 375 (1911) (names of witnesses before a grand jury); Green v. Bomar, 329 F.2d 796 (6th Cir. 1964) (right to examine witnesses at a preliminary hearing in a state capital offense proceeding); United States v. Johnson, 129 F.2d 954 (3d Cir. 1942) (exclusion of defendant from courtroom during argument on question of law); Curtis v. Rives, 123 F.2d 936 (D.C. Cir. 1941) (failure of Government to produce certain key witnesses) ; cf., Snyder v. Massachusetts, 291 U.S. 97 (1934) (refusal to take defendant with the jury when it went to view the scene of the crime); Hutson v. State, 296 S.W.2d 245 (Tex. Crim. App. 1956) (impeachment of defendant's witness by tape recording).

16 The standard collections of constitutional documents were consulted. E.g., 1-5 Elitot's Debates on the Federal Constitution (2d ed. 1861) ; Farrand, Tak Records of the Convention of 1787 (1911); The Federalist Papers. See also Cooley, Constitutional Limititions *318 (4th ed. 1878). 
that all the words of the Constitution have a real present meaning unless otherwise proven. ${ }^{17}$ The strength of the language of the clause as reasonably interpreted and the fact that courts have consistently given it objective content by interpreting it in light of the hearsay rule ${ }^{18}$ make such an assumption reasonable.

\section{A. Federal Standards for the Right to Confrontation}

The Supreme Court has said that the confrontation clause includes important rights to the individual, which the Court "has been zealous to protect . . . from erosion." 19 However, the Supreme Court has never fully articulated federal standards required by the confrontation clause in a hearsay evidence context. ${ }^{20}$ Dicta in several cases further confuse any attempt to discern a definite federal standard. In one case Mr. Justice Cardozo recognized that "the privilege of confrontation at [no] time [has] been without recognized exceptions. . . The exceptions are not even static, but may be enlarged from time to time if there is no material departure from the reason of the general rule." 21 Unfortunately he provided no indication of what the "reason of the general rule" was. In another case the Court stated that the purpose of the confrontation clause is to "continue and preserve" the right to confrontation as it existed at common law and "not to broaden it or disturb the exceptions." 22

Moreover, the Supreme Court has rarely been called upon to decide whether the right to confrontation will be extended to specific factual situations. In one of the earliest cases to reach the Court, it held that where the Government negligently allowed a witness to flee, the witness' testimony from a preliminary hearing could not be admitted at trial because of the sixth amendment's requirement. ${ }^{23}$ And the Court later held that the admission of the trial record of a defendant's alleged accomplices to

17 See, e.g., Wright v. United States, 302 U.S. 583, 587-88 (1938); United States v. Butler, 297 U.S. 1 (1936) ; Myers v. United States, 272 U.S. 52 (1926); Ogden v. Saunders, 25 U.S. (12 Wheat.) 213 (1827).

18 See, e.g., Salinger v. United States, 272 U.S. 542, 548 (1926); Kirby v. United States, 174 U.S. 47 (1899); United States v. Cardillo, 316 F.2d 606, 610 (2d Cir.), cert. denied, 375 U.S. 822 (1963); cf. Brown v. United States, 234 F.2d 140 (6th Cir. 1956), aff'd, 356 U.S. 148 (1958).

19 Greene v. McElroy, 360 U.S. 474, 497 (1959).

20 Compare Robertson v. Baldwin, 165 U.S. 275, 282 (1897) (dictum).

21 Snyder v. Massachusetts, 291 U.S. 97, 107 (1934).

22 Salinger v. United States, 272 U.S. 542, 548 (1926). Compare Kay v. United States, 255 F.2d 476, 480 (4th Cir.), cert. denied, 358 U.S. 825 (1958), in which the court stated that the clause was "intended to prevent the trial of criminal cases upon affidavits, not to serve as a rigid and inflexible barrier against the orderly development of reasonable and necessary exceptions to the hearsay rule."

23 Motes v. United States, 178 U.S. 458 (1900). Compare Mattox v. United States, 156 U.S. 237 (1895). 
show that property was in fact stolen from the United States violated the confrontation guarantee. ${ }^{24}$

If any federal standard can profitably be distilled from the few cases squarely presenting the issue, that standard would be that the right to confrontation gives a criminal defendant the opportunity to face and effectively ${ }^{25}$ cross-examine the witnesses who are testifying against him. ${ }^{26}$ The extent to which these witnesses can be other than the original declarant depends upon whether the historically evolved exceptions to the hearsay evidence rule provide constitutionally adequate protection for the defendant. $^{27}$

24 Kirby v. United States, 174 U.S. 47, 61 (1899). The Court has also sidestepped a real constitutional discussion by finding that the evidence objected to was not hearsay, and thus no confrontation was necessary. Salinger v. United States, 272 U.S. 542 (1926) (letters written by third parties were answered by the defendant and thus adopted by him); Dowell v. United States, 221 U.S. 325 (1911) (certification of facts by the judge and clerk on how a trial was conducted).

25 See Garcia v. State, 210 S.W.2d 574 (Tex. Crim. App. 1948) (failure to provide translator when defendant could not understand English violated state confrontation clause); accord, State v. Vasque, 101 Utah 444, 121 P.2d 903 (1942).

26 But a fact which can be primarily established only by witnesses cannot be proved against an accused . . . except by witnesses who confront him at the trial, upon whom he can look while being tried, whom he is entitled to cross-examine, and whose testimony he may impeach in every mode authorized by the established rules governing the trial $\mathrm{nr}$ conduct of criminal cases.

Kirby v. United States, 174 U.S. 47, 55 (1899).

27 The Supreme Court has rejected application of the confrontation clause to the states. See, e.g., Stein v. New York, 346 U.S. 156 (1953) ; Snyder V. Massachusetts, 291 U.S. 97 (1934); West v. Louisiana, 194 U.S. 258 (1904). The states have also consistently accepted this view. See, e.g., People v. Ashley, $42 \mathrm{Cal}$. $2 \mathrm{~d}$ 246, 267 P.2d 271, cert. denied, 348 U.S. 900 (1958). Compare In re Oliver, 333 U.S. 257 (1948); Campbell v. State, 11 Ga. 353 (1852).

In Stein v. New York, supra, the Court affirmed a conspiracy conviction which had been based in part upon the confessions of two co-conspirators which implicated the petitioner. The Court stated that the "hearsay-evidence rule, with all its subtleties, anomolies and ramifications, will not be read into the Fourteenth Amendment." Id. at 176. However, the Court recently has shown an increasing tendency to protect individuals against state action by means of federal standards. See, e.g., Malloy v. Hogan, 378 U.S. 1 (1964). The right to cross-examine the opposing witnesses may perhaps be considered a liberty so basic that such protection is required. See Kirby v. United States, 174 U.S. 47, 56 (1898); United States ex rel. Jones v. Myers, 226 F. Supp. 343 (E.D. Pa. 1964) (dictum). Compare United States v. Rosenberg, 195 F.2d 583, 596 (2d Cir.), cert. denied, 344 U.S. 838 (1952) (hearsay admitted without objection is to be given its natural probative effect on appeal), with United States v. Dunn, 299 F.2d 548 (6th Cir. 1962) (even though not objected to, hearsay which provides sole grounds for conviction will be considered error under FED. $R$. Crma. P. 52(b)). See generally Antieau, Commentaries on the Constitutron OF THE UNITED States 181 (1960).

Recently, a federal district court in Gray v. Wilson, 230 F. Supp. 860, 862 (S.D. Cal. 1964), held that "the right of the accused to cross-examine and confront prosecution witnesses in a state criminal trial is guaranteed by the due process clause of the Fourteenth Amendment." The Government had offered only a transcript of the preliminary hearing into evidence, claiming that the defendant waived his right to confrontation when he waived a jury trial. The court found no specific waiver and thus granted habeas corpus. However, the court apparently used the notion of fairness in due process instead of the confrontation clause to reach this conclusion, for it felt compelled by Wilner v. Committee on Character, 373 U.S. 96 (1963), which held that a lawyer was guaranteed the right to cross-examine those who testified against him in a state administrative proceeding. 


\section{B. The Hearsay Rule and the Right to Confrontation}

\section{Historical Interrelationship}

Although the language of the confrontation clause is absolute, it has always been interpreted as admitting some exceptions in the hearsay context. ${ }^{28}$ The framers may not have intended to establish the hearsay rule itself as the fundamental value of the right to confrontation, but it is reasonable to infer that they were willing to accept the then existing exceptions to the rule as permissible trial practices. However, the assumption that only those hearsay exceptions which existed at the time of the sixth amendment's adoption are constitutional ${ }^{29}$ seems without merit. Exceptions to the common-law hearsay rule were devised almost concurrently with the statement of the rule because of a realization that justice otherwise would be defeated. ${ }^{30}$ But the established exceptions had gone through a gradual and at times confusing development by the 1790 's, and others were still in the process of being refined. ${ }^{31}$ To create a constitutional

28 See, e.g., Mattox v. United States, 156 U.S. 237 (1895). For some early state decisions in this area, see State v. Mc O'Blenis, 24 Mo. 402 (1857); Summons v. State, 5 Ohio St. 325 (1856).

29 Compare note 27 , supra; note 31 infra. at 130 .

30 See generally 9 HoLDSWORTH, op. cit. sispra note 3, at 219; 5 WIGMORE § 1397,

31 Perhaps motivated by the trial of Sir Walter Raleigh, who was convicted on hearsay evidence, the English courts developed a strong policy against the admission of hearsay by the 1700's. See generally HeLLER, THE SIXTH AMrENDMENT 104 (1951); 5 WIGMORE $\$ 1364$, at 21,24 . The courts almost concurrently developed a few exceptions-Wigmore's treatise provides an excellent historical survey. Id. \$\$1430, 1476. Compare Levie, Hearsay and Conspiracy, 52 MrcE. L. REv. 1159, 1161-63 (1954) (conspiracy exception did not develop till 1794-96). But the courts gave ground grudgingly thereafter when new exceptions were posed. See Sussex Peerage Case, [1844] 11 Cl. \& F. 85, 109-14, 8 Eng. Rep. 1034, 1043-46; Berkeley Peerage Case, [1811] 4 Camp. 401 , 171 Eng. Rep. 128. Some of the early exceptions grew out of the necessity caused by the lack of adequate registry systems, id. at 421,171 Eng. Rep. at 137; and thus the only way to establish some points of pedigree and boundary was by hearsay through, for example, family bibles or common knowledge. See generally 5 WIGmore $\$ \$ 1480$ (pedigree), 1563 (boundaries). Compare Mima Queen v. Hepburn, 11 U.S. ( 7 Cranch) 290 (1813). Since all states now have recording statutes for land and for vital statistics, it might be questioned whether the necessity argument used to justify the admission of this evidence is still valid. See generally Note, 46 Iowa L. REv. 414 (1961). In any event no criminal case could be found in which the exception of pedigree or boundary was used.

The English courts initially received book entries only when made by persons who had died and did not receive the party's own entries even though the party could not have testified himself at trial. See generally 5 WIGMORE $\$ \S 1476,1518$. Because of this quirk in the early procedure, the party's books were eventually admitted. However, when the parties were finally permitted to testify, the exception was continued. Id. $\S 1518$, at 350 .

The dying declaration exception was initially accepted in both criminal and civil trials. Wright $v$. Littler, [1761] 3 Burr. 1244, 1253. However, by the American Revolution, the English courts had apparently restricted it only to homicide cases. Stobart v. Dryden, [1836] 1 M. \& W. 614, 150 Eng. Rep. 581. But see 5 WIGMoRe $\S 1431$, at 220 . Moreover, some exceptions did not actually congeal until the nineteenth century. Statements against interest were not mentioned in this early period. Spontaneous utterances were not mentioned specifically, but were hinted at in discussions about other exceptions as to the likelihood of reliability being increased as a statement nears the event. Berkeley Peerage Case, supra at 408,171 Eng. Rep. at 131; Rawson v. Haigh, [1824] 2 Bing. 99, 103, 130 Eng. Rep. 242, 244. And the law on 
rule based on an arbitrary date when the law was quite unclear would seem to run counter to the notion of a gradual constitutional reevaluation in light of society's present attitudes. ${ }^{32}$ Similarly, even if the framers actually considered the exceptions existing in 1791, it does not follow inexorably that the original exceptions are still constitutional.

It has also been suggested that the framers merely meant to place the complete abolition of the hearsay rule beyond the power of legislatures. ${ }^{33}$ Although the clause, as so interpreted, apparently would not require standards for the admission of specific hearsay, legislatures could easily undermine the entire effectiveness of the hearsay rule by enacting very liberal exceptions. ${ }^{34}$ This possibility demonstrates that a constitutional evaluation of each exception is necessary to preserve the basic right.

Both the right to confrontation and the hearsay rule reflect the belief that some evidence which might be of probative value should not be admitted unless the declarant has actually appeared in court and has been cross-examined with regard to his sincerity, memory, perception, and ability to communicate. ${ }^{35}$ When courts have admitted hearsay in criminal trials, they have generally attempted only to fit the evidence within one of the established common-law hearsay exceptions which have developed because of a certain notion of potential trustworthiness, or because of necessity. ${ }^{36}$ However, the purpose of the common-law exceptions appears to be to facilitate the admission of probative evidence. ${ }^{37}$ These exceptions have evolved from a weighing of the need to receive the evidence at trial, the unavailability of the declarant, the assumed trustworthiness of the statement, and the risk that the jury will not properly assess the weight to be given to the statement. But in a criminal trial, these considerations must be balanced in light of the requirement of the sixth amendment, which has as its prime goal the protection at trial of an accused faced with the possibility of criminal sanctions.

testimony taken at prior proceedings was similarly unsettled by the 1790 's. In Rex v. Eriswell, [1790] 3 T.R. 707, 722, 100 Eng. Rep. 815, 823, a court upheld the admissibility of testimony of a then deceased declarant who had testified at a coroner's inquest at which the defendant was not present, for the judicial proceeding itself assured the trustworthiness. Although this was a civil case, Rex v. Baker, [1746] 2 Strange 1240, 93 Eng. Rep. 1156, was a criminal case with a similar holding. Accord, Rex v. Westbeer, [1739] 1 Leach 12, 168 Eng. Rep. 108 (deposition without defendant's cross-examination). However, in subsequent cases the courts excluded such former testimony unless the defendant had been present at the first proceeding and had a chance to cross-examine the witness. See, e.g., Rex v. Vipont, [1761] 2 Burr. 1163, 97 Eng. Rep. 767.

32 See United States v. Classic, 313 U.S. 299, 316 (1941); Barton v. United States, 263 F.2d 894, 898 n.6 (5th Cir. 1959). See generally Miller, Notes on the Concept of the "Living" Corstitution, 31 GEO. WASH. L. REv. 881 (1963).

33 See 5 WIGMORE $\$ 1397$, at 127.

34 See Matthews v. United States, 217 F.2d 409, 418 (5th Cir. 1954).

35 See generally Morgan, Maguire \& Weinstein, Cases on Evidence 167-68 (4th ed. 1957).

36 See, e.g., Cox v. State, 3 N.Y.2d 693, 148 N.E.2d 879, 171 N.Y.S.2d 818 (1958). But cf. Dallas County v. Commercial Union Assur. Co., 286 F.2d 388, 397 (5th Cir. 1961). See generally 5 WIGMORE $\$ \S 1421-23$.

37 See generally McCoRarick $\$ 300$. 


\section{Constitutional Standards for Hearsay Exceptions}

The trial judge in a criminal case should admit hearsay statements only if the defendant is afforded an adequate substitute for confrontation. ${ }^{38}$ The importance of the offered evidence to the litigation, which may be a consideration in civil trials where the courts must finally assess liability for loss, is of no relevance in criminal cases, where the presumption of innocence protects the accused throughout the trial. Moreover, the critical nature of a criminal trial demands that a stricter assurance of trustworthiness and a stricter finding of necessity be established. ${ }^{39}$

In the establishment of potential trustworthiness, the mere assumption that a situation minimizes the chance of falsification ${ }^{40}$ is not sufficient. Judges may properly consider the rationales of the established exceptions, but should not be bound by them. They should particularly not rely inflexibly upon categories based upon assumptions which may be reasonably challenged by objective or psychological tests ${ }^{41}$ or upon values which are no longer dominant in our society. And a careful determination of necessity will also insure that apparently trustworthy hearsay will not be admitted when the original declarant could be easily produced.

Finally, the courts must weigh the importance to the defendant of cross-examination of the declarant on the hearsay statement. When the witness is present at trial, the defendant can force him to clarify ambiguities and explain contradictions in his testimony, while the jury is able to observe his demeanor as a factor in assessing credibility. The defendant should not be denied this opportunity unless the issues that would be probed on cross-examination are not generally significant in the trier of the fact's evaluation of the particular evidence. Although issues of credibility are not generally grounds for exclusion of hearsay statements, they are of prime importance in criminal trials because of the greater reluctance to risk misuse by the jury.

However, if the accused has a reasonable opportunity effectively to rebut the effect of the hearsay, and if the likelihood of an inaccurate report of the facts seems slight, hearsay can be admitted without violating the accused's rights. ${ }^{42}$ Although courts have always been reluctant to admit offered hearsay which did not fall within any of the traditional categories, ${ }^{43}$ this reaction is not constitutionally compelled where the court satisfies

38 There can never be a fully adequate substitute for cross-examination, for there is always the possibility that under effective cross-examination a witness will demonstrate to the jury his unsuredness or mendacity.

39 See Snyder v. Massachusetts, 291 U.S. 97, 107 (1934) ; Kirby v. United States, 174 U.S. 47, 56, 60 (1899); cf. Stein v. New York, 346 U.S. 156, 196 (1953).

40 See text accompanying notes 46-50 infra.

41 See Quick, supra note 10 , at 210 .

42 Compare Mattox v. United States, 156 U.S. 237, 242 (1895).

43 See, e.g., Cox v. State, 3 N.Y.2d 693, 148 N.E.2d 879, 171 N.Y.S.2d 818 (1958). Compare United States v. Grunewald, 164 F. Supp. 644 (S.D.N.Y. 1958) (recognizing trend toward greater admissibility of hearsay in federal courts). 
itself that the high standards of trustworthiness and necessity and the reasonable assurance that cross-examination would be unavailing have been met.

\section{The Constitutionality of Hearsay in Criminal Trials}

In many instances the innovations of the Uniform Rules of Evidence have relieved the restrictive effect of traditional hearsay exceptions. This sudden development necessitates constitutional analysis not only of the expanded exceptions, but also of the traditional rationales of admissibility.

\section{A. Dying Declarations}

The dying declaration exception generally permits the admission of statements of a homicide victim pertaining to the crime if the declarant was aware of imminent death-a mental state which is thought to supply the assurances of trustworthiness. ${ }^{44}$ The exception has existed almost as long as the hearsay rule itself. ${ }^{45}$ Apparently, most American courts have assumed, in effect, the propriety of this exception either with no real discussion of trustworthiness or with a reliance on the notion that one could not die with a lie on his lips; ${ }^{46}$ other courts have stressed only the element of necessity. ${ }^{47}$ However, the constitutionality of this exception depends primarily upon the validity of the assumption that the consciousness of impending death compels men to tell the truth.

The assumption that a man could not face the unknown of death with a deceit on his mind was made apparently by good and religious men and gives no credit to the scoundrel or bumbler who seeks revenge or is mistaken even in death. ${ }^{48}$ It is unlikely that the moments before death will ever be fully catalogued so that the world knows what goes on in a man's mind. Although it may appear overly skeptical to question a rule based primarily upon a fundamental religious belief in an after-life, the Constitution would seem to require a more objective test of trustworthiness. Notwithstanding the undoubted recognition of this exception by the framers, the existence of a more secular society raises a reasonable doubt whether the declarant felt compelled to speak the truth, a doubt which should be resolved in favor of the defendant. Moreover, when a man is

44 See generally MCCORMICK $\$ 260 ; 5$ WIGMoRe $\$ 1445$; Falknor, The Hearsay Rule and Its Exceptions, 2 U.C.L.A.I. REv. 43, 67 (1954). The declarant must also be competent to testify were he alive.

45 See note 31 supra.

46 See, e.g., Mattox v. United States, 156 U.S. 237 (1895); Tracey v. State, 97 III. 101,106 (1880).

47 See, e.g., Carver v. United States, 164 U.S. 694, 697 (1896); Donnelly v. State, 26 N.J.L. 601,617 (1857). Several other courts have confused the area with a res gestae discussion. See Pendleton v. Commonwealth, 131 Va. 676, 704, 109 S.E. 201,211 (1921). (1960).

48 See Quick, Some Reflections on Dying Declarations, 6 How. L.J. 109, 112 
near death, his excited state of mind, as well as his physical transformation, may dull his ability to perceive facts and to relate them accurately..$^{48}$

Notwithstanding these insurmountable objections, all courts, including the Supreme Court, which have considered the point have assumed the constitutionality of this exception. ${ }^{50}$ However, the Court has never been forced to make such a specific holding, ${ }^{51}$ and it expressed great skepticism about the trustworthiness of dying declarations while holding that the common law would permit a defendant to introduce rebuttal evidence. ${ }^{52}$ In an attempt to reach a compromise, some courts have indicated that a dying declaration, if uncorroborated, may not sustain a conviction. ${ }^{53}$ However, this would seem to weaken the necessity justification, which attempts to prevent a guilty defendant from benefiting from the death of the only witness. Other courts treat rebuttal evidence that the declarant was not a religious man as only affecting the weight of the evidence, not its admissibility. ${ }^{54}$ But this approach seems manifestly erroneous, even if the underlying assumption of the exception is held constitutionally adequate, because substantial evidence of the declarant's lack of religious belief would destroy the rationale for trustworthiness.

Despite the unreliability of dying declarations, the Uniform Rules adopted this exception without constitutional discussion. ${ }^{65}$ In fact the New Jersey and California studies treat its trustworthiness as a foregone conclusion. However, the Utah study-in what must be an attempt to increase the assurances of reliability-proposed a requirement that the judge find that "the declarant . . . had an adequate opportunity to perceive the event or condition which his statement narrates, describes or explains." ${ }^{56}$ Although this requirement would not seem to demand an investigation of the declarant's coherence at the time of the statement or of the existence of a bias against the defendant, it is an enlightened first step

49 See text accompanying note 62 infra. Perhaps a determination of the nature of the decedent's wound or cause of death should be made. Compare State v. Stewart, 30 N.M. 227, 236, 231 Pac. 692, 696 (1924).

50 See, e.g., Campbell v. State, 11 Ga. 353 (1852); Summons v. State, 5 Ohio St 325 (1856); State v. Saunders, 14 Ore. 300, 12 Pac. 441 (1886); Robertson v. Baldwin, 165 U.S. 275, 282 (1897) (dictum); Mattox v. United States, 156 U.S. 237 (1895) (dictum); cf. People v. Corey, 157 N.Y. 332, 51 N.E. 1024 (1898) (statutory confrontation provision).

51 But see 5 WIGMORE $\S 1398$, at 141.

52 Carver v. United States, 164 U.S. 694, 697 (1896).

53 See Hill v. State, 64 Miss. 431 (1886) (dictum); Lambeth v. State, 23 Miss. 322 (1852) (by implication). Compare Goodall v. State, 1 Ore. 335 (1861).

54 See Nesbit v. State, 43 Ga. 238, 249 (1871) ; People v. Abella, 47 Phil. I. 731 (1925). Courts will also allow evidence of passion, hatred, or revenge. See, e.g., Commonwealth v. Gardner, $282 \mathrm{~Pa} .458,128$ Atl. 87 (1925) (the declarant even made inconsistent statements-but both were admissible).

65 UNIFORM RULE of EVIDENCE 63(5): "[I]f the judge finds that [the declaration] .. was made voluntarily and in good faith and while the declarant was conscious of his impending death and believed there was no hope of his recovery." Accord, Kan. Laws 1963, ch. 303, § 60-460(e).

56 See UTAH Study 36. 
in searching for a more rational basis for admission than ancient assumptions.

The Uniform Rules also extended the dying declaration exception to civil trials, because it had been illogically applied only to homicide cases. ${ }^{57}$ Conceding the illogicality of the prior restriction, it is unfortunate that the Uniform Rules would extend and perpetuate the use of an exception of such questionable reliability. Somewhat inexplicably, New Jersey restricted the exception's use to any criminal case. ${ }^{58}$ Since the basis of trustworthiness is equally doubtful whether the trial is criminal or civil, this partially illogical limitation seems to be based upon an extension of the common-law necessity rationale that a wrongdoer may have removed one of the key witnesses.

\section{B. Excited Utterances}

Another exception which is also based upon the assumption that one in an excited state of mind is incapable of premeditation to serve his own interests is that of excited utterances. ${ }^{59}$ The specific requirements of the exception all relate to the spontaneity of the statement-it must be made while nervous excitement dominates, and it must relate to the startling occurrences which the declarant observed personally. ${ }^{\text {Bo }}$ Even if it is assumed that excitement prevents a deliberate misstatement, ${ }^{61}$ the prerequisites for admission under this exception offer constitutionally inadequate protection for the accused.

Psychological studies indicate that excitement may severely impair the declarant's ability accurately to perceive and communicate. ${ }^{62}$ Although these factors generally go to the weight rather than to the admissibility of trial testimony, they assume greater importance in the hearsay context. When an eye-witness testifies at trial, the defendant's most valuable weapon is the opportunity to probe the witness' subjective abilities so that the jury may consider his responses and demeanor in assessing the credibility of his testimony. It is this opportunity that the right to confrontation seeks to preserve, and it is this opportunity for which an adequate substitute must be provided. And since the eye-witness' ability to perceive accurately is most often as important as his sincerity in asserting the

57 See generally 5 WigmoRe $\S \S 1432,1436$; CAL. Study 472.

68 The New Jersey recommendations had suggested that dying declarations be admitted in civil trials under the rationale of rule 63(4)(c). See 1963 N.J. REPORT 153; text accompanying note 177 infra. $\S 1745$.

59 See, e.g., Dismukes v. State, 83 Ala. 287 (1887). See generally 6 Wrgarore

60 See Slough, Spontaneous Statements and State of Mind, 46 IowA L. REv. 224, 242 (1961). Compare Clark v. Van Vleck, 135 Iowa 194, 112 N.W. 648 (1907) (excluded because not sufficiently spontaneous).

01 See generally 6 WIGmoRe \$ 1749; Slough, supra note 60 , at 240.

62 See Hutchins \& Slesinger, Some Observations on the Law of Evidence, 28 CoLUM. L. REv. 432 (1928). See also Kubie, Implications for Legal Procedure of the Fallibility of Human Memory, 108 U. PA. L. REv. 59 (1959). 
facts when the testimony is weighed, there would seem to be no adequate substitute for having the witness make his assertions in person.

Where the declarant's statement is ambiguous or made under circumstances which raise a reasonable doubt as to his perceptive abilities, such as temporary incoherency caused by the event, ${ }^{63}$ the evidence should be excluded. Similarly, if the defendant introduces evidence calling into question the credibility of the statement, the prosecution should have the burden of persuading the judge that cross-examination of the declarant on this issue would not be of significant importance. However, if the judge finds that the statement is unambiguous and was made while the declarant's powers of perception and communication were unimpaired, then it may constitutionally be admitted.

The Uniform Rules' spontaneous and contemporaneous statement exception would admit statements which the judge finds were "made while the declarant was under the stress of a nervous excitement caused by [the] perception [of an event]." 64 The common-law requirement of unavailability was eliminated, apparently on the notion that an excited utterance is "far superior to an in-court statement tested by crossexamination." ${ }^{65}$ However, the states have been unwilling to adopt the Uniform Rules' proposal without further assurances of adequate trustworthiness. Consequently, the California study recommended the addition of a finding of spontaneity, ${ }^{66}$ while $\mathrm{New}$ Jersey enacted a version which would require that the statement have been made "in reasonable proximity to the event [perceived] and without opportunity to deliberate or fabricate." ${ }^{67}$ However, both additions are merely consistent with the commonlaw assumption of trustworthiness; neither considers the possibility that the excitement might have dulled the declarant's senses. ${ }^{68}$ To give the accused an adequate substitute for his right to confrontation, the judge should be required to make this additional investigation.

\section{Statements Against Interest}

A third exception based upon assumptions about human nature is the admission of statements against the declarant's interest. Thus, if the witness is unavailable, ${ }^{69}$ such prior statements may be admitted at trial ${ }^{70}$ on the theory that men do not normally state facts against their interest unless they are true. ${ }^{71}$ For many years this exception had been restricted

63 Cf. Guthrie v. United States, 207 F.2d 19, 23 (D.C. Cir. 1953).

64 UNIFORM RULe OF EvIDENCE 63(4)(b); accord, Kan. Laws 1963, ch. 303, $\S 60-460$ (d) (2); UTAH STUDY 35.

65 CAL. STUdy 466; cf. McCoRMick \$257, at 554.

66 Cal. Study 317-18; 1963 N.J. Report 146.

67 N.J. Sup. CT. R. Evidence 63(4) (b).

68 See Quick, supra note 10 , at 210.

69 But see People v. Spriggs, 60 Cal. 2d 868, 875-76, 389 P.2d 377, 381-82, 36 Cal. Rptr. 841, 845-46 (1964).

70 See generally 5 WIGMORE $§ \S 1463,1465$.

71 See id. \$1457. See generally Morgan, Declarations Against Interest, 5 VAND.

L. REv. 451 (1952). 
to facts against pecuniary interest. ${ }^{72}$ Recently, courts have realized that there is no rational distinction between statements against pecuniary and penal interests in their probabilities of trustworthiness and have thus admitted both types of statements. ${ }^{73}$

Although it seems reasonable that no man would state a fact which might cause him to suffer financial loss or imprisonment, the Constitution must protect defendants from statements of unreasonable men if there is to be no opportunity for cross-examination. The underlying theory of reliability seems to presuppose the unlikely factual situations in which people are conscious of the ultimate legal implications of their speech. This exception also fails to recognize motives which may cause people to make unfavorable statements about themselves. Since the declarant is not available, the accused cannot effectively probe the truth of the remark or the reasons, however tenuous, for making it. Thus, if the defendant can present persuasive evidence rebutting the trustworthiness of the statement, such as declarant's lack of knowledge of the facts, or an attack on the underlying assumption, such as a motive which may have caused declarant to fabricate, the hearsay should be excluded.

In this area the Uniform Rules expanded the common law to admit statements which "so far subjected [the declarant] ... . to civil or criminal liability" at the time of their assertion "that a reasonable man in his position would not have made the statement unless he believed it to be true." 74 Both the Utah and California studies recommended the addition of the common-law requirement of unavailability of the declarant. ${ }^{75}$ Although this addition would supply the essential finding of necessity, it does not approach the fundamental problem of finding reliability upon unproved theories of motivation. ${ }^{78}$ In response to this difficulty, New Jersey has restricted the exception's use in criminal trials to those which were made by the defendant. ${ }^{77}$ As limited, the exception raises no confrontation problems because of the presence of the defendant at the subsequent trial. $1044-45$

72 See Sussex Peerage Case, [1844] 11 Cl. \& F. 109, 111-12, 8 Eng. Rep. 1034,

73 See, e.g., Mason v. United States, 257 F.2d 359 (10th Cir.), cert. denied, 358 U.S. 831 (1958); People v. Spriggs, 60 Cal. 2d 868, 875, 389 P.2d 377, 381, 36 Cal. Rptr. 841, 845 (1964); Band's Refuse Removal, Inc. v. Borough of Fair Lawn, 62 N.J. Super. 522, 561, 163 A.2d 465, 486 (App. Div.), certification denied, 33 N.J. 387, 164 A.2d 849 (1960) (extended at least when a public statute is being challenged). Compare Commonwealth v. Antonini, 165 Pa. Super. 501, 69 A.2d 436 (1949) (declaration against interest of third party which exculpates defendant held inadmissible), with Donnelly v. United States, 228 U.S. 243, 273-77 (1913) (exculpating confession held inadmissible). In Doinelly Mr. Justice Holmes, dissenting, pointed out that an inculpating dying declaration would be held admissible. Id. at 278.

74 UNIFORM Rule of EvIDence 63(10); accord, Kan. Laws 1963, ch. 303, $\S 60-460(j)$.

75 Cat. Study 323; Utah Study 37. But see Cal. Study 501.

70 But see MCCORMICK $\$ 257$, at 554, stating that these declarations are "just as credible as [declarant's] present testimony would be."

77 N.J. Sup. CT. R. Evidence 63(10). Compare 1963 N.J. Report 168. 


\section{Conspiracy}

The out-of-court statement of a co-conspirator implicating the defendant has been held admissible when made during the course of a conspiracy, irrespective of whether the defendant was present when the statement was made or of whether the declarant is available at trial. ${ }^{78}$ Although the courts impose the additional requirement that the statement must have been made in furtherance of the conspiracy, ${ }^{79}$ such statements may be admitted even if a conspiracy was not formally charged, ${ }^{80}$ subject only to the condition that the conspiracy be proved by direct evidence. ${ }^{81}$ Even if the jury is accurately charged to ignore the statement until it finds a conspiracy and then to consider the hearsay in deciding whether the defendant was a participant, the defendant is inadequately protected because such a complex analysis would seem realistically beyond the jurors' abilities. ${ }^{82}$

The admission of a co-conspirator's hearsay statements subject to later "tying up" may perhaps be justified by the difficulties in proving conspiracy. ${ }^{83}$ But even if the jury is able to comply with the charge, the defendant's guilt may in fact be determined on the basis of hearsay evidence. Most courts make no independent analysis of the reliability of such statements. ${ }^{84}$ In Delaney v. United States ${ }^{85}$ the Supreme Court held that the right of confrontation was not violated by the admission of hearsay statements made in furtherance of a conspiracy by a co-conspirator, apparently without considering the trustworthiness of or necessity for the evidence. The Court relied upon several prior conspiracy cases which had not posed

78 See Krulewitch v. United States, 336 U.S. 440 (1949); United States v. Sapperstein, 312 F.2d 694 (4th Cir. 1963); United States v. Mesarosh, 223 F.2d 449, 455 (3d Cir. 1955), rev'd and remanded on other grounds, 352 U.S. 1 (1956). This hearsay exception has long been accepted. See United States v. Gooding, 25 U.S. (12 Wheat.) 460 (1827). See generally WIILIAMS, CrIMINAL LAW $\$ 218$ (2d ed. 1961) (suggesting that before the judge decides on the admissibility of the hearsay he should make a preliminary determination of defendant's guilt) ; Levie, Hearsay and Conspiracy, 52 MICH. L. REv. 1159 (1954); Note, 62 Harv. L. Rev. 276 (1948); Note, 25 U. ChI. L. Rev. 530 (1958). State decisions follow this formulation. See, e.g., Commonwealth v. Evans, $190 \mathrm{~Pa}$. Super. 179, 154 A.2d 57 (1959).

79 See Krulewitch v. United States, supra note 78, at 444; Yokely v. United States, 237 F.2d 455, 458 (9th Cir. 1956); Briggs v. United States, 176 F.2d 317, 320 (10th Cir.), cert. denied, 338 U.S. 861 (1949). Compare United States v. Hall, 178 F.2d 853 (2d Cir. 1950) (confession of co-conspirator after conspiracy ended held inadmissible). See generally McCorMIcK \$245, at 521-25.

80 See United States v. Pugliese, 153 F.2d 497 (2d Cir. 1945) (L. Hand, J.).

81 Id. at 500; Mayola v. United States, 71 F.2d 65, 67 (9th Cir. 1934).

82 See United States v. Delli Paoli, 229 F.2d 319, 321 (2d Cir. 1956), aff'd, 352 U.S. 232 (1957); Nash v. United States, 54 F.2d 1006, 1007 (2d Cir.), cert. denied, 285 U.S. 556 (1932).

83 See Levie, supra note 78, at 1166.

84 Id. at 1163-67.

85263 U.S. 586 (1924). 
constitutional issues and held that the judge had not abused his discretion in admitting the statements. ${ }^{86}$

Several analogies have been made to other hearsay exceptions to justify the admission of a co-conspirator's statement, but the comparisons are not compelling. ${ }^{87}$ For instance, initially to consider these statements as vicarious admissions ${ }^{88}$ confuses the relationship among conspirators with that of principal and agent. The practical considerations which justify forcing a principal to adopt, for business and evidence purposes, the statements of his authorized agent ${ }^{89}$ are not present with a conspiracy, because its members often lack the power to control or authorize other members' actions..$^{90}$ Nor does it follow that because the substantive law of conspiracy holds one conspirator accountable for all acts during the conspiracy, ${ }^{91}$ hearsay of one conspirator can be admitted to show that the defendant was a member of the conspiracy. The confrontation clause cannot be so simply ignored by establishing through hearsay the basic fact necessary to justify the admission of hearsay statements under the substantive law of conspiracy. ${ }^{92}$

The fact that the statements are against the interests of the declarant might be a sufficient rationale for admitting his statements relevant to his participation in the conspiracy. ${ }^{93}$ But the assumption that reasonable men do not say things against their interests does not logically extend the inference of reliability to a statement against the interest of another person. As in any other context, the members of a conspiracy might incriminate

86 Id. at 590. In Schine Chain Theatres, Inc. v. United States, 334 U.S. 110 (1948), which involved no constitutional discussion, the Court stated that as long as the hearsay is made within the limits of the conspiracy and a conspiracy is shown "by independent evidence, these inter-office letters and memoranda were admissible against all conspirators as declarations of some of the associates so far as they were in furtherance of the unlawful project." Id. at 117. Despite the general language of the Schine case and the holding of the Delaney case, the Court has attempted to resist "attempts to broaden the already pervasive and wide-sweeping nets of conspiracy prosecution." Grunewald v. United States, 353 U.S. 391, 404 (1957). However, neither Grunewald nor the authority cited in that case involved confrontation considerations.

87 See generally Levie, supra note 78; Note, 25 U. CHI. L. REv. 530 (1958). Some courts have even used the confusing label of res gestae See, e.g., United States v. Gooding, 25 U.S. (12 Wheat.) 460 (1827). See generally 6 WIGMrore $\S 1745$; CAL. STUdy 465.

88 See, e.g., Gambino v. United States, 108 F.2d 140, 142 (3d Cir. 1939).

89 See United States v. Miller, 246 F.2d 486 (2d Cir.), cert. denied, 355 U.S. 905 (1957) (criminal case). See generally 1963 N.J. REPORT 165; Morgan, The Rationale of Vicarions Admissions, 42 HARv. L. Rev. 461 (1929); Note, 25 U. CHI.

L. REv. 530, 533-34 (1958).

80 See Morgan, supra note 89, at 481; Note, 25 U. CHI. L. REv. 530, 535 (1958).

01 See Van Riper v. United States, 13 F.2d 961, 967 (2d Cir.), cert. denied, 273 U.S. 702 (1926). See also Hetland, Admissions in the Uniform Rules: Are They Necessary?, 46 Iowa L. REv. 307, 328-29 (1961).

92 See Gambino v. United States, 108 F.2d 140 (3d Cir. 1939); Van Riper v. United States, 13 F.2d 961 (2d Cir.), cert. denied, 273 U.S. 702 (1926). See generally Note, 25 U. Chr. I. Rev. 530, 539 (1958). Compare Kirby v. United States, 174 U.S. 47,56 (1898).

93 See text accompanying notes $70-73$ supra. 
other individuals either because of revenge or mistake. ${ }^{94}$ Furthermore, the conspiracy situation may provide strong motivation to fabricate with regard to the involvement of innocent parties if the claim of their participation would further the group's ends. Thus this exception must stand on its own justification-which seems simply to be that the secret nature of conspiracy or any joint endeavor necessitates the admission of this evidence. However, the difficulties of proving conspiracy should not justify the abrogation of the right to confrontation.

In light of the lack of an independent rationale or of an adequate substitute for cross-examination to test the truthfulness of a co-conspirator's statements, it might be doubted whether their admission would be constitutional. However, the Constitution would be satisfied if the judge were to make an independent finding of reliability based on the specific case. ${ }^{95}$ But the scope of review of such a determination should not be confined by the rubric of trial judges' "discretion." 96

The Uniform Rules broadened the conspiracy exception to admit statements "relevant" to the conspiracy or its subject matter made while the "party and declarant were participating in a plan to commit a crime or a civil wrong" and before its termination.97 Both the California and New Jersey commissions feared the unfairness of the sweep of this rule and restricted it to statements made in furtherance of the plan. ${ }^{.8}$ And according to the California recommendation, independent proof must be made of the existence of the conspiracy and participation by the declarant and the defendant before the declarations may be admitted.99 These additions would not seem to relieve the doubt about the trustworthiness of these statements. Finally the Uniform Rules' virtual abandonment of any necessity factor by the elimination of the unavailability requirement would seem to make this exception constitutionally unacceptable without further qualification.

\section{E. Prior Testimony}

Some hearsay statements are admitted on the grounds that the defendant had a prior opportunity to test the reliability of the statement

94 See generally Levie, supra note 78, at 1172 ("lies and gossip spread during the course of a criminal scheme"). The author also suggests that hearsay during the pendency of the conspiracy should be excluded if the declaration is self-serving. Ibid.

95 Compare United States v. Delli Paoli, 229 F.2d 319, 322 (2d Cir. 1956), aff'd, 352 U.S. 232 (1957).

${ }^{96}$ Compare text accompanying note 86 supra.

97 UNIFORM RULE OF EVIDENCE 63(9) (b) ; accord, Kan. Laws 1963, ch, 303, $\$ 60-460$ (i) (2); UTAF STUDY 37. The Uniform Rules would also require that the statement, if it had been made in court, would have been admissible. This requirement is not based upon the confrontation clause, but arises from considerations which would not allow a rule of public policy, such as the exclusion of privileged statements, to be defeated by calling the evidence an exception to the hearsay rule.

98 Cal. Study 321; 1963 N.J. Report 164 (followed in N.J. Sup. Ct. R. Evidence $63(9)(\mathrm{b}))$.

99 CAL. Study 321. 
by cross-examining the declarant ${ }^{100}$ on a similar issue. ${ }^{101}$ Thus depositions ${ }^{102}$ and testimony given at preliminary hearings ${ }^{103}$ or at prior trials ${ }^{104}$ will normally be admitted under this rationale. The necessity for the use of the hearsay is assured by a further requirement that the witness must be dead, or, if alive, must not be within the jurisdiction of the court. ${ }^{105}$

Several decisions based upon the right to confrontation have been rendered concerning this type of hearsay. ${ }^{106}$ While the reasoning of these cases is often unenlightening, ${ }^{107}$ the fact that the defendant has had a prior opportunity to cross-examine supports the holdings that these statements may be constitutionally admitted. It is, of course, true that the jury is unable to consider the demeanor of the declarant in assessing the credibility of his testimony. But with a prior opportunity to cross-examine, the defendant may reveal faults in the memory and perception of the witness or uncover his personal motivations, all of which may indicate the unreliability of his statements. Under the analysis presented in this Note, the defendant's ability to show these weaknesses by independent impeaching evidence would not indicate that other hearsay statements, such as spontaneous declarations, should be admitted if the defendant has impeachment evidence. With prior testimony the fact that declarant himself has explained contradictions or clarified ambiguities in his testimony closely approximates

100 See Mattox v. United States, 156 U.S. 237 (1895) ; Coppedge v. United States, 311 F.2d 128, 132 (D.C. Cir. 1962), cert. denied, 373 U.S. 946 (1963); State v. Head, 91 Ariz. 246, 371 P.2d 599 (1962); Reynolds v. United States, 98 U.S. 145 (1879) (dictum). Compare Harrell v. United States, 220 F.2d 516 (5th Cir. 1955) (example of prior testimony which does not raise confrontation problems in a subsequent perjury suit). See generally 5 WIGMORE $\$ 1398(1)$.

101 State v. Kenstler, 49 S.D. 551, 207 N.W. 535 (1926). Compare Shaw v. United States, 1 F.2d 199, 201 (8th Cir. 1924).

102 See generally 5 WIGMORE $\$ 1398$, at 140 n.5; Note, 46 IowA L. REv. 356 (1961). When the Government is to take a deposition, it must give the defendant sufficient notice of when it is to take place. Compare United States v. French, 117 Fed. 976 (D. Ore. 1902) ; FEd. R. CRIM. P. 15 (e).

103 See State v. Tyler, 187 Kan. 58, 353 P.2d 801 (1960) (dictum); cf. State v. Ortego, 22 Wash. 2d 552, 157 P.2d 320 (1945) (testimony given at a Justice of the Peace's hearing where no actual record was kept). Compare Fotie v. United States, 137 F.2d 831 (8th Cir. 1943) (defendant absent from the preliminary hearing).

104 McBride v. State, 368 P.2d 925 (Alaska 1962), cert. denied, 374 U.S. 811 (1963); State v. Jordan, 83 Ariz. 248, 320 P.2d 446, cert. denied, 357 U.S. 922 (1958).

105 See Mattox v. United States, 156 U.S. 237 (1895); Motes v. United States, 178 U.S. 458 (1900) (by implication). It is generally considered the prosecutor's responsibility to conduct a diligent search for the witness. See West v. Louisiana, 194 U.S. 258 (1904); People v. Redston, 139 Cal. App. 2d 485, 293 P.2d 880 (Dist. Ct. App. 1956); Commonwealth v. Gallo, 275 Mass. 320, 175 N.E. 718 (1931) (excellent review of the common-law history of this exception). Compare White v. Dowd, 164 F. Supp. 266 (N.D. Ind. 1958); State v. Brown, 181 Kan. 375,312 P.2d 832 (1957) (examples of insufficient proof of unavailability). If the declarant is not absent through the negligence of the prosecution, the admission of his testimony does not violate the confrontation clause. See Motes v. United States, supra. See generally 1963 N.J. REPORT 145.

108 See text accompanying notes 23-24 supra.

107 E.g., Mattox v. United States, 156 U.S. 237 (1895). 
the defendant's opportunities were the deciarant present at trial. The resulting high assurance of reliability would seem to provide adequate protection for the defendant.

However, the generally reliable nature of prior testimony should not relieve the trial judge of protecting the defendant against potential untrustworthiness. In Mattox v. United States, ${ }^{108}$ the Supreme Court, employing the common denominator of the dying declaration exception, ${ }^{109}$ upheld the admissibility of prior testimony, although the defendant was prohibited from impeaching the dead witness' testimony because he had not laid a proper foundation at his first trial. ${ }^{110}$ However, it seems unjustifiable to deny the defendant the right to impeach the hearsay testimony. If the defendant is denied his right to cross-examine the witness at trial, he should be permitted to present to the jury the same evidence, relevant to its determination of the weight to be given the hearsay statement, that he would have been able to present if the declarant had been actually present. Similarly, if the defendant uncovers new evidence bearing upon the credibility of the declarant, the judge should determine whether the trustworthiness of the prior testimony has been so impaired that it would be unreasonably prejudicial if the defendant were denied the right to question the declarant before the jury.111

On the other hand, the question remains whether the trial judge's independent consideration of the reliability of hearsay statements may properly result in the admission of prior testimony, even where the defendant did not have a prior opportunity to cross-examine. In Young $v$. United States, ${ }^{112}$ which held that the introduction of the witness' grand jury testimony as probative evidence while the witness was on the stand at the trial violated the defendant's right to confrontation, the court emphasized that the defendant had not been able to cross-examine the witness

108156 U.S. 237 (1895).

109 The Court stated that "no one would have the hardihood at this day to question" the admissibility of the dying declaration. Id. at 243 .

110 Compate UNIForM Rule of Evidence 65.

The Supreme Court had reversed Mattox's first conviction. Mattox v. United States, 146 U.S. 140 (1892). In the instant Mattox case the Court stated that the general rules, such as the right to confrontation, "however beneficient in their operation and valuable to the accused, must occasionally give way to considerations of public policy and the necessities of the case." 156 U.S. at 243. And the Court continued:

[T]o say that a criminal, after having once been convicted by the testimony of a . . . witness, should go scott free simply because death has closed the mouth of that witness, would be carrying his constitutional protection to a unwarrantable extent. The law in its wisdom declares that the rights of the public shall not be wholly sacrificed in order that an incidental benefit may be preserved to the accused.

Ibid. (Emphasis added.)

111 In Coppedge v. United States, 311 F.2d 128 (D.C. Cir. 1962), cert. denied, 373 U.S. 946 (1963), the court prevented the defendant from rebutting the prior testimony by a signed recantation because of the requirements of authentication of documents. The procedure of authentication should perhaps be liberalized in these hearsay situations.

112214 F.2d 232 (D.C. Cir. 1954). 
at the grand jury hearing. ${ }^{113}$ But where the witness is unable to remember the facts presented in his prior testimony, the record may be admitted if the court finds that the testimony was given under such circumstances as to insure its trustworthiness. ${ }^{114}$ Under these circumstances the defendant can probe the witness himself as to motivation to fabricate and his general perception.

Another consideration which should be determinative of the admissibility of prior testimony is the identity of parties and issues at the prior hearing. In Kirby v. United States, ${ }^{115}$ the Supreme Court held that the admission of the record of the trial at which defendant's alleged accomplices were convicted to prove the existence of the crime was constitutionally impermissible. ${ }^{116}$ Although the interest of the defendant on this issue was identical to the interests of the defendants at the prior trial, the confrontation clause would seem to require that a defendant not be bound by the adequacy of the representation of another party. Even if the defendant had been a party to the prior proceeding, the courts should also require that the issues in the two proceedings be similar. Cross-examination on an issue not in the trial may not only be tactically dangerous, but it would undoubtedly be held to be irrelevant. ${ }^{117}$ Yet the Commissioners did not see fit to impose any identity-of-parties requirement in the Uniform Rules' exception for depositions and prior testimony, despite the obvious abridgment of the right to confrontation. ${ }^{118}$ The states which have considered the Uniform Rules' proposal have either questioned the constitutionality of this exception or taken moves to avoid the issue. The Utah Commission's notes to this exception state that no exception is designed to violate the constitutional right to confrontation, ${ }^{119}$ and the Kansas enact-

113 See People v. Hobson, 369 Mich. 189, 194, 119 N.W.2d 581, 584 (1963) (dissenting opinion) (admission of police memoranda as substantive evidence when he could not recall facts was thought to violate the state confrontation clause because the witness could not be effectively cross-examined and the memoranda had no protective characteristics of trustworthiness).

114 See Note, 112 U. PA. L. REv. 1133, 1164 (1964) (suggestion that when grand jury proceedings where the defendant has no right to cross-examine were conducted several years after the events, they may be used to refresh the witness' memory, but not as past recollection recorded). But see UNIFORM RULE OF EvIDENCE 63(1).

115174 U.S. 47 (1899).

116 See Barone v. United States, 205 F.2d 909, 914 (8th Cir. 1953).

117 Compare State v. Kenstler, 49 S.D. 551, 207 N.W. 535 (1926) ; Miles v. State, 268 P.2d 290, 298 (Okla. Crim. Ct. App. 1954) (dictum) (defendant waived his confrontation right when he offered part of the prior civil testimony in a subsequent criminal trial). In Graham v. United States, $136 \mathrm{Ct}$. Cl. 324 (1956), cert. denied, 353 U.S. 917 (1957), the Court of Claims held that the testimony given at a courtof-inquiry was constitutionally admissible at a subsequent court-martial even though the incentive to defend oneself might not be as great at a court-of-inquiry. Although it might be doubted whether the incentives to defend are in fact different because of the possible damaging effect on a military career resulting from a court-of-inquiry, the defendant actually had an opportunity to cross-examine which he should have exercised as effectively as possible. Accord, Narum v. United States, 287 F.2d 897 (Ct. Cl. 1960), cert. denied, 368 U.S. 848 (1961).

118 UNIFORM RULE of EVIDENCE 63(3) (the deposition must be taken according to state law).

119 Uta Study 35. 
ment states that "the provision [of this exception] shall not apply in criminal actions if it denies the accused the right to meet the witness face to face . . . ."120 Both the New Jersey tentative adoption ${ }^{121}$ and the California recommendation ${ }^{122}$ met the issue positively and restricted the use of former testimony by the prosecutor in criminal trials to instances when the present defendant was a party to the prior proceedings and had the opportunity for cross-examination with an interest and motive similar to that of the subsequent proceeding. Leaving aside the constitutionally necessary identity-of-parties requirement it is interesting to note that this exception has evoked more constitutional discussion on the part of the revisors than any other, ${ }^{123}$ yet it is the only exception where there has at least been $a$ confrontation.

\section{F. Prior Judgments}

The instances of using prior judgments in subsequent criminal trials will be few, except in the habitual criminal situation, ${ }^{124}$ because criminal charges are normally joined and criminal trials normally precede civil trials. ${ }^{125}$ The introduction of a prior judgment in a subsequent criminal trial poses a possible violation of the defendant's right to confrontation. ${ }^{128}$ Such evidence is hearsay when it is offered to prove the truth of an element contained in the judgment which the defendant cannot presently crossexamine. ${ }^{127}$ The judicial policy of putting an end to litigation over the

$120 \mathrm{Kan}$. Laws 1963 , ch. $303, \S 60-460$ (c).

121 N.J. Sur. Cr. R. EvIDENCE 63(3).

122 CAL. STUDY 314-15 recommends the division of this exception into two subsections: $63(3)$, former testimony offered against a party to the former proceeding; and 63(3.1), former testimony offered against a person not a party to the former proceeding. Both CAL. STUDY 450 and 1963 N.J. REPORT $139-45$ contain extended discussion as to the applicability of the right to confrontation to this hearsay exception. The New Jersey study concludes by doubting its constitutionality if applied to other than the original parties.

123 Even the Uniform Rules Commissioners raised this doubt. See UNIFORM RULE OF EVIDENCE 63(3), comment.

124 Some state legislatures have determined that two or more convictions characterize a criminal as habitual. But these statutes do not really raise a significant confrontation problem, for a copy of the judgment would seem to offer few opportunities for inaccuracies. The judgment itself is being offered into evidence at the second trial simply to show that the defendant had been convicted, which would not affect the conviction at the second trial, against which the defendant has a complete chance to defend. It would, however, affect the sentencing. See, e.g., State v. Johnson, 194 Wash. 438, 78 P.2d 561 (1938). See generally Note, 46 IowA L. Rev. $400,410-11$ (1961).

125 See 46 Iowa L. Rev. 400, 412 (1961). But see United States v. Konovsky, 202 F.2d 721, 726-27 (7th Cir. 1953) (submission of a civil judgment into a criminal trial held unconstitutional).

126 Judgments entered into evidence in subsequent civil trials raise no confrontation issue, but a prior judgment might still be excluded on straight evidentiary principles. See, e.g., Interstate Dry Goods Stores v. Williamson, 91 W. Va. 156, 112 S.E. 301 (1922) (larceny conviction in subsequent suit to recover goods). See generally Cowen, The Admissibility of Criminal Convictions in Subsequent Civil Proceedings, 40 CALIF. L. REv. 225 (1952).

127 See generally 5 WIGMORE $\$ 1671$ (a); Note, 46 IowA L. REv. 400 (1961): Compare CAI. STUDY 540: "the statement of a jury embodied in its verdict is sui generis," standing "apart from other kinds of written and oral statements." 
subject matter and the defendant's prior opportunity to defend himself might be used to justify this exception to the hearsay rule. ${ }^{128}$ By analogy to the above discussion on prior testimony, if the prior party was someone other than the present defendant, acceptance of the former judgmenteven assuming an equal motivation for the first party to defend-would deny to the present defendant that guarantee which belongs only to him. ${ }^{128}$ Furthermore, the defendant should always be permitted to offer evidence to rebut the effect of the judgment. ${ }^{130}$

The confrontation guarantee would probably be satisfied if the present defendant had an adequate opportunity and incentive to defend himself on an identical issue in a prior criminal trial. Under these circumstances litigation of the issues would have provided the first jury with all that the second jury would have. ${ }^{131}$ If the prior judgment was rendered in a civil case, however, it should not be admitted in a criminal case because of the danger that a jury may overemphasize its probative value by not comprehending the less rigorous burden of proof. Moreover, the pressures to settle or compromise a civil action are so great, especially where the damages are likely to be inconsequential, that it would be unreasonable to consider the defendant's previous presentation as an adequate substitute for his present right to confrontation. ${ }^{132}$

Similar doubts about the constitutionality of admitting a prior judgment would arise if the first trial had been for a minor criminal offense, such as many traffic or nuisance violations, ${ }^{133}$ where the defendant might have pled guilty to avoid further expenses of litigation. Where the prior judgment is entered upon a guilty plea, the probative weight of the evidence depends upon assumptions similar to those underlying the declarationsagainst-interest exception, ${ }^{134}$ rather than upon an earlier jury's weighing of fully contested evidence. The subsequent death of a traffic-accident victim, resulting in an indictment for manslaughter, would expose a defendant to a heavy burden of rebuttal if the court admits his guilty-plea conviction on a prior reckless driving charge. In view of the existence of motives other than consciousness of guilt which would lead a defendant to enter a guilty plea in these cases, these judgments should not be used to shift the burden of persuasion.

The formulation of the prior judgments exception in the Uniform Rules permits the admission of a prior conviction of a felony to prove a fact essential to sustain the judgment. ${ }^{135}$ The Commissioners realized that they had gone beyond most common-law rulings in this area and purposely

128 Compare Morrison v. State, 267 Ala. 1, 100 So. 2d 744 (1957).

129 See generally CAL. STUDY 541.

130 The Supreme Court in Kirby v. United States, 174 U.S. 47 (1899), appeared more concerned with the conclusiveness of the prior judgment than with its actual admission.

131 See generally 5 WIGMORE $\$ 1671$ (a), at 689.

132 Cf. Note, 46 IowA L. REV. 400, 412-13 (1961).

133 See 1963 N.J. REPORT 196-99.

134 See text accompanying notes 69-73 supra.

135 UNIFORA RULE OF EvIDENCE 63(20); accord, Kan. Laws 1963, ch. 303, $\S 60-460(r)$. UTAR StUdy 40. 
limited the exception to felony judgments, where the incentive to defend presumably would be greatest. ${ }^{136}$ However, they imposed no identity-ofparties requirement. The New Jersey tentative adoption properly restricted the exception as formulated to subsequent civil trials ${ }^{137}$-accepting its study's suggestion that the "stakes are too high" in a criminal case. ${ }^{138}$ California's commission rejected the exception completely, finding no "pressing necessity" for it, particularly since prior testimony and guilty pleas could be admissible under other exceptions. ${ }^{139}$ Although the confrontation clause would not require the outright rejection of this exception, at least not if an identity-of-parties requirement were added, hearsay exceptions need not be geared to a constitutional minimum.

\section{G. Business Records}

If writings or other records were made during the regular course of business, they may be admitted, without producing the maker of the records, to prove the facts which they contain..$^{140}$ In most jurdisdictions, as well as in the federal system, this common-law exception has been codified. $^{141}$ The necessity for the admission of this evidence is based primarily on the difficulty, if not impossibility, of establishing many business occurrences by direct evidence, ${ }^{142}$ for both clerks and top executives cannot possibly remember every transaction. The trustworthiness justification is based upon the reliance by businessmen themselves on records made in the regular course of business procedure or routine. ${ }^{143}$

The business records statutes have generally met with judicial approval..$^{144}$ Although the exception has been upheld in the criminal

136 UNIFORM RULE OF EVIDENCE 63(20), comment.

137 N.J. SuP. CT. R. Evidence 63(20).

1381963 N.J. REPORT 197.

139 CAL. Study 331. In a further study it was suggested that the Uniform Rules should be limited to prior judgments against the present defendant-although the author of that study did not believe this to be necessary. Id. at 539-41.

140 See generally MCCORMICK \$286; 5 WrGMORE §§ 1521-33; Laughlin, Business Entries and the Like, 46 IowA L. Rev. 276 (1961).

141 See, e.g., 28 U.S.C. $\$ \$ 1732-33$ (1958), as amended, 28 U.S.C. $\$ 1732$ (b) (Supp. V, 1964); UNIFORM RULE OF EvIDENCE 63(13). See generally 1963 N.J. REPORT 177-88; Laughlin, supra note 140, at 276-77, 305.

142 See Palmer v. Hoffman, 318 U.S. 109, 112 n.3 (1943).

143 See Matthews v. United States, 217 F.2d 409, 413-14 (5th Cir. 1954) ; 1963 N.J. REPORT 179-80; Laughlin, supra note 140 , at 277 . But see Orfield, The Hearsay Rule in Federal Criminal Cases (pt. 2), 32 ForDHAM L. REv. 769, 771 (1964).

If the court finds that the records were not made within the regular course of business, they will be excluded. See, e.g., United States v. Mortimer, 118 F.2d 266 (2d Cir. 1941) ; McKnight v. Broedell, 212 F. Supp. 45 (E.D. Mich. 1962). Compare Bisno v. United States, 299 F.2d 711, 718 (9th Cir. 1961), cert. denied, 370 U.S. 952 (1962) (mere fact that memorandum was taken from chronological files and was in form of letter does not detract from reliability).

144 See generally Emerson, Business Entries: Their Status Under the Uniform Rules and Present Law, 26 U. CINC. L. REv. 591 (1957) ; Polasky \& Paulson, Business Entries: From Common Law to the New Uniform Rules of Evidence, 4 UTAF I. REv. 327 (1955). 
context against constitutional objections, ${ }^{145}$ civil cases for the most part provided the background for these decisions. ${ }^{148}$ For example, United States v. Leathers ${ }^{147}$ held that the Federal Business Records Act did not violate the confrontation guarantee because "records kept as a matter of ordinary routine are often likely to be more reliable than dying declarations," 148 which the court assumed to be constitutional. However, in another case the admission of records made by a sugar dealer which were required to be filed with the Internal Revenue Service was held error because they were neither business nor official records. ${ }^{149}$ The court apparently based its decision upon Palmer v. Hoffman, ${ }^{150}$ which turned upon whether an accident report made by defendant's employee was made in the regular course of business. But, in fact, the court was concerned that the records did not contain sufficient indicia of trustworthiness. Since this latter criterion was not a ground for exclusion under the statute, ${ }^{151}$ the court relied upon a test that was contained therein. The court found that the federal act itself was constitutional, but, in its analysis of the right to confrontation, the court said that hearsay must be required by great necessity and possess "adequate guarantees of trustworthiness. . . [O] therwise . . . Congress could abolish the right of confrontation by making unlimited exceptions to the hearsay rule." 152 The court's desire to protect the defendant's constitutional rights is undoubtedly the reason why the records were excluded on statutory grounds. ${ }^{153}$

The admission of business records does not in general offend the confrontation clause, for the natural motivation to excel in one's endeavor would normally insure accurate business records..$^{154}$ However, the fact

145 The Supreme Court has never been forced to decide this issue. For examples of state decisions, see State v. Guaraneri, 59 R.I. 173, 194 At1. 589 (1937) (dictum) (hospital records made within regular course of business not inadmissible because of the state confrontation clause, which does not alter rules of evidence); Waxler v. State, 67 Wyo. 396, 224 P.2d 514 (1950).

146 See United States v. Leathers, 135 F.2d 507, 511 (2d Cir. 1943); Olender v. United States, 237 F.2d 859, 866 (9th Cir. 1956), cert. denied, 352 U.S. 982 (1957). The statutes grew out of the shop-book rule and the regular-entries rule. See 5 WIGMORE \$1518; Laughlin, supra note 140 , at $277-78$ \& n.3.

147135 F.2d 507 (2d Cir. 1943).

148 Id. at 511 .

149 Matthews v. United States, 217 F.2d 409 (5th Cir. 1954) ; accord, Luttrell v. United States, 320 F.2d 462 (5th Cir. 1963). But see State v. Smith, 74 Iowa 580, 38 N.W. 492 (1888) (dictum) (pharmacist's monthly statements to county treated as official records).

150318 U.S. 109 (1943).

151 See Orfield, supra note 143 , at 771 .

152 Matthews v. United States, 217 F.2d 409, 418 (5th Cir. 1954).

153 One court in a recent case considered the constitutionality of the federal act a foregone conclusion. United States v. Johns-Manville Corp., 225 F. Supp. 61 (E.D. $\mathrm{Pa} .1963)$. The Government in that case conceded in its memorandum in opposition, id. at 63 \& n.3, that it should always produce the maker of an important record "wherever possible" because of the sixth amendment. The decision rendered was probably correct because the issue was posed at a pretrial hearing where no evidence was before the court.

154 The assumption that reasonable men do not usually make incriminating statements is also included in the justification. See text accompanying notes $69-73$ supra. 
that evidence fits the statutory definition of "business records" should not of itself determine that it is constitutionally admissible. The reliance upon records in the business world seems to depend more on the same necessity which justifies their admissibility at trial, rather than any intrinsic trustworthiness of business accounting and reporting systems. Thus, if the defendant can sufficiently demonstrate to the court that the record may be unreliable, it should be excluded. Although several of the statutes provide that such evidence concerning trustworthiness goes only to the weight to be given the record and not to its admissibility, 155 the judge should be free in a criminal trial to exclude evidence if it appears to him that the defendant will be significantly prejudiced by not having an opportunity to cross-examine someone who presently remembers the transaction. 156

The Uniform Rules qualify the standard business records exception by requiring the judge to firid that "the sources of information from which [the records were] made and the method and circumstances of their preparations were such as to indicate their trustworthiness." 157 The great significance of this formulation is that the defendant's evidence showing the untrustworthiness of the offered business records is no longer restricted to the weight to be given the hearsay. Thus the trial judge may exclude the hearsay when its trustworthiness does not meet the high standards demanded by the right of confrontation.

The Uniform Rules require no finding of unavailability, apparently because of the belief that facts recorded soon after the occurrence of an event will be more accurate than testimony at trial. However, the California study correctly recommended that the custodian of the records must testify as to their identity and mode of preparation. 158 In view of the importance to the defendant of showing the unreliability of the record, he should not have the burden of finding and producing the proper witnesses. The Constitution would seem to require some showing of extreme inconvenience or impossibility in not producing the maker of the records to give direct testimony-particularly when the records are essential to the prosecution's case. ${ }^{159}$

\section{H. Official Records}

When writings or reports of public officials are made under official authority, they will normally be admitted as probative evidence without

165 E.g., 28 U.S.C. $\$ 1732$ (1958).

$156 C f$. Laughlin, supra note 140 , at 295-96.

157 UNIFORM RULE OF EviDENCE 63(13); accord, Kan. Laws 1963, ch. 303, §60$460(\mathrm{~m})$; N.J. Sup. CT. R. Evménce 63(13); Utaf Study 38. UNIForM Rule of EvmENCE $62(6)$ includes, within the definition of "business," organizations conducted for nonprofit. Compare CAL. STUDY 326, which includes this definition within its proposed exception.

See 1963 N.J. REPORT 180-88 for an excellent discussion of the various factual situations which might arise under this exception.

158 CAL. Study 326.

159 Cf. United States v. Johns-Manville Corp., 225 F. Supp. 61, 63 (E.D. Pa. 1963). If the makers were required to take the stand, they could always refresh their memory with the writing. UNIFORM RULE OF EVIDENCE 63 (1). 
production of the original maker being required. ${ }^{160}$ The necessity for this exception is usually expressed in terms of the inconvenience to certain officials and the resulting general disruption of public business; ${ }^{101}$ the assurances of trustworthiness derive from the official's responsibility to the public to make accurate records ${ }^{162}$ and the public's opportunity to correct mistakes. ${ }^{163}$ Although courts have in general held this exception constitutional, ${ }^{164}$ the mere label of "official record" should not eliminate the need for a strict appraisal of the truthfulness of the record.

The momentous events of a man's life, birth, marriage, and death are officially and publicly recorded, ${ }^{165}$ and so it is not constitutionally unreasonable to produce these documents to prove the facts stated therein rather than a doctor or minister whose memory may have failed.166 However, when the record is not open to public inspection, when there is no duty to report, or when the report is too evaluative, ${ }^{167}$ the accused might be denied his right to confrontation. Should the accused in a murder trial whose defense is suicide be forced to have the coroner's report that death resulted from homicide admitted without an opportunity to cross-examine its maker on the reasons for his conclusion? ${ }^{168}$ Even with an official's lack of motivation to falsify, the introduction of his out-of-court opinions ${ }^{169}$ as opposed to his routine recordation of facts-raises crucial questions of memory, perception, and method of analysis. If the defendant can ade-

160 See generally 5 WIGMoRe $\$ \$ 1630-84 ; 1963$ N.J. Report 188-92; Wallace, Official Written Statements, 46 Iowa L. REv. 256 (1961).

101 See, e.g., State v. Torello, 103 Conn. 511, 131 Atl. 429 (1925) ; Commonwealth v. Coldsmith, $176 \mathrm{~Pa}$. Super. 283, 106 A.2d 649 (1954); T'Kack v. United States, 242 F.2d 937 (5th Cir. 1957) (alternative holding); Olender v. United States, 210 F.2d 795 (9th Cir. 1954) (dictum).

162 See Greenbaum v. United States, 80 F.2d 113, 125-26 (9th Cir. 1935).

163 See United States v. Elder, 232 Fed. 267 (W.D. Ky. 1916); Sturla v. Freccia, 5 App. Cas. 623 (1880). Compare 5 Wigmore \$1634.

164 See, e.g. Kay v. United States, 255 F.2d 476 (4th Cir.), cert. denied, 358 U.S. 825 (1958) (blood analysis in a drunken driving case); Bracy v. Commonwealth, $119 \mathrm{Va}$. 867,89 S.E. 144 (1916) (chemist's report in an illegal sale of liquor case) ; People v. Dolgin, 415 Ill. 434, 114 N.E.2d 389 (1953) (Department of Revenue reports). See 5 WrGMORE $\$ 1398$, at $141 \mathrm{n} .8$ which cites Dowdell v. United States, 221 U.S. 325 (1911), as upholding the constitutionality of this exception. But the Dozedell case only holds that the trial judge and clerk, whose certification to the Philippine Supreme Court on how the trial was conducted, were not witnesses against the accused within the meaning of the sixth amendment. See generally Wallace, supra note 160 , at 272 . See State v. Wilson, 141 La. 404, 75 So. 95 (1917), in which a state statute providing that a certificate from the Internal Revenue Service that a person was issued a federal permit was prima facie evidence that he violated state licensing law was held to violate the confrontation right.

105 See, e.g., State v. Nage1, 75 N.D. 495, 28 N.W.2d 665 (1947) (birth certificate); cf. Phelan v. United States, 249 Fed. 43 (9th Cir. 1918) (baptismal record). Compare Austin v. United States, 208 F.2d 420 (5th Cir. 1953) (death certificate not admissible on identity of deceased); State v. Green, 161 La. 620, 109 So. 143 (1926) (use of a death register certificate to show death violates confrontation right when it could be shown orally).

168 Cf. 1963 N.J. REPORT 189. On statements recorded by ad hoc officials, see Matthews v. United States, 217 F.2d 409, 417 n.3 (5th Cir. 1954).

167 See 1963 N.J. REPORT 192.

168 Cf. 27 N.Y.U.L. REv. 158 (1952).

169 See State v. Torello, 103 Conn. 511, 520, 131 Atl. 429, 431 (1925). 
quately demonstate to the court that an effective cross-examination might sufficiently challenge this testimony, it would seem that the confrontation clause requires that the evidence be excluded.

Under the Uniform Rules reports or findings of fact made by public officials are admissible if the official had a duty to make the report, and if it was his duty "(a) to perform the act reported, or (b) to observe the act, condition or event reported, or (c) to investigate the facts concerning the act, condition or event and to make findings or draw conclusions based on such investigation." 170 In light of the constitutional objections to the admission of evaluative reports, ${ }^{171}$ it is unfortunate that the Commissioners expanded the common-law exception, especially where a conclusion is not based upon first-hand information, to include such evaluative statements. Perhaps in response to objections based upon the declarant's right to confrontation, the various state studies have significantly limited the exception's scope. The Utah study excluded traffic accident reports entirely and specifically limited the use of the admissible writings to the factual data contained therein. ${ }^{172}$ Similarly, the New Jersey tentative adoption limited the use of the reports based upon investigation to their statistical findings. ${ }^{173}$ Kansas did not adopt this exception at all.

The California study discarded the Uniform Rules' formulation and recommended that reports be admitted if, in addition to the normal duty requirement, the judge finds that the record was made soon after the time of the act or event, and that the sources of information and method of preparation were such as to indicate its trustworthiness. ${ }^{174}$ The comments indicate that this modification was designed to allow evaluative reports. ${ }^{175}$ However, the judge's finding of trustworthiness, in this instance, would seem to take no account of ill-considered conclusions by the official or defects in perception in his sources of information, and thus would not meet the necessary confrontation standards.

\section{I. "Necessity"-Uniform Rule 63(4)(c)}

In another effort to unchain the hearsay rule, the Uniform Rules established a virtually new exception entitled "necessity," which had its only basis in several statutes allowing hearsay in civil trials if the declarant had died. ${ }^{176}$ Thus statements are admissible when made by a

170 UNIFORAS RULE OF EVIDENCE 63(15).

171 The Uniform Rules would require that a copy of the evaluative report be delivered to the defendant before trial at the risk of exclusion. UNIFORM RULE OF EVIDENCE 64.

172 UTAH StUDy 38-39.

173 N.J. Sup. CT. R. Evidence 63(15).

174 CAL. STUdY 327-28.

175 See id. at 328.

176 See, e.g., Mass. ANn. Laws ch. 233, §65 (1956); R.I. Gen. Laws Ann. \$9-19-11 (1956) (no limitation to civil cases, but there appear to be no reported criminal cases); Evidence Act, 1938, 1 \& 2 Geo. 6, c. 28. Compare MODEL CoDE OF EVIDENCE rule 503(a) (unavailability is only test for admission of hearsay), criticized in Gard, The Uniform Rules of Evidence, 31 Tus. L. REv. 19, 23-25 (1956). 
declarant who is unavailable, "narrating, describing or explaining an event or condition which the judge finds was made by the declarant at a time when the matter had been recently perceived by him and while his recollection was clear, and was made in good faith prior to the commencement of the action." 177 In the comment to this exception, the Commissioners emphasize that it was so drafted "to indicate an attitude of reluctance and require most careful scrutiny in admitting hearsay statements under its provisions." 178 Several recent civil decisions, apparently following the spirit of this section, have relied upon the "necessity" of the case for the probative use of hearsay. ${ }^{179}$

In their appraisal of this exception, the states were primarily concerned with protection of the defendant's constitutional rights. ${ }^{180}$ New Jersey's adoption, in fact, restricted further its study's recommendation that the exception be applied only to civil cases, by permitting such hearsay in civil cases only when the declarant is dead. ${ }^{181}$ The California commissioners recommended its rejection, presumably, however, because of a fear of abuse in personal injury cases. ${ }^{182}$ The Utah study recommended adoption only if the statements were restricted to writings. ${ }^{183}$ And Kansas adopted the exception, but required an additional finding by the judge that the declarant had "no incentive to falsify or to distort." 184 While such a finding would seem to be encompassed by the notion of "good faith," this specific requirement further cautions the trial judge to provide an adequate substitute for the accused's confrontation guarantee.

This new exception provided by the Uniform Rules has been both approved ${ }^{185}$ and criticized ${ }^{188}$ by authorities who have considered its potential effect upon the right to confrontation. One commentator, who has questioned the constitutionality of the "necessity" exception, was particularly critical of the complete lack of an objective indication of trustworthiness. ${ }^{187}$ Clearly, a test which would allow the whims of a judge to

177 UNIFORM RULE OF EVIDENCE 63(4) (c). For a liberal definition of "unavailable as a witness," see UNIFORM RULE of EVIDENCE $62(7)$.

178 UNIFORM RULE OF EVIDENCE 63(4), comment.

179 E.g., Dallas County v. Commercial Union Assur. Co., 286 F.2d 388 (5th Cir. 1961) (necessity equated with probative value of and lack of accepted category for the hearsay - an old newspaper); Moore v. Atlanta Transit Sys., Inc., 105 Ga. App. 70, 84, 123 S.E.2d 693, 702 (1961) ; Band's Refuse Removal, Inc. v. Borough of Fair Lawn, 62 N.J. Super. 522, 557-61, 163 A.2d 465, 484-86 (App. Div.), certification denied, 33 N.J. 387, 164 A.2d 849 (1960).

180 See, e.g., N.J. REPORT 148-53. The commissioners were also worried about the "practical wisdom" of applying this exception to criminal cases. Id. at 151.

181 N.J. Sur. CT. R. Evidence 63(32).

18: See Cal. Study 318.

183 UTAH STUDY 35.

$184 \mathrm{Kan}$. Laws 1963, ch. 303, $\$ 60-460$ (d).

185 Chadbourn, Bentham and the Hearsay Rule-A Benthamic View of Rule $63(4)(c)$ of the Uniform Rules of Evidence, 75 Harv. L. Rev. 932 (1962); McCormick, Hearsay, 10 RuTGERs L. REv. 620, 624 (1956).

186 Quick, Hearsay, Excitement, Necessity, and the Uniform Rules: A Reappraisal of Rule 63(4), 6 WAYNe L. REv. 204, 214-21 (1960).

187 Id. at 219-24; cf. 1963 N.J. REPORT 152. 
decide whether cross-examination would be beneficial would not give the defendant the full protection of confrontation. It may also be argued that if the constitutionally required determination of trustworthiness cannot be uniformly applied, then it would be better to exclude the evidence than have one defendant the victim of a judge's overly liberal view of hearsay. However, this cynical view of trial judges would seem to ignore the fact that they have been, or should have been, making independent determinations whether the reliability of hearsay sought to be admitted under the established exceptions meets the rigorous constitutional standards. ${ }^{188}$ Moreover, the trial judge would have the benefit of his past experience with hearsay in determining trustworthiness of the evidence, as well as any available studies or investigations on the trustworthiness of statements made under various fact situations. ${ }^{180}$ And his determination, if not encumbered by the "discretion" rubric, will be subject to appellate review.

Indeed, this exception would seem to provide a more secure safeguard than reliance upon the traditionally accepted categories. For where a hearsay exception is readily available, judges often mechanically fit the evidence into an established niche without carefully appraising its credibility. But recent analysis has revealed that many exceptions are based upon assumptions about human conduct, ${ }^{190}$ often remnants of an earlier era, ${ }^{191}$ which do not take account of significant factors of unreliability. The new Uniform Rules' exception is more sensitive to constitutional standards by requiring a determination whether cross-examination would be necessary to protect the accused. And it offers the distinct benefit of having the judge actually pass upon the credibility of the declarant before the jury receives his statements ${ }^{102}$ - a basis for exclusion which reflects the primary advantage the defendant obtains when he can confront the witness himself in front of the jury.

James $W$. Jennings

188 The problem of the overzealous prosecutor who might spirit off some of the witnesses, making them unavailable, would not seem to be as great as it might seem, for the courts should be able to control this situation by a finding of diligent search. See note 105 sipra.

189 See, e.g., Hutchins \& Slesinger, Some Observations on the Law of Evidence, 28 ColuM. L. REV. 432 (1928).

190 See text accompanying notes 46-48, 69-73 supra.

191 E.g., the dying declaration. See also note 31 supra.

192 See Cal. Study 463. Compare Note, 46 Il.. L. Rev. 915 (1952). 